\title{
Marek Jeziński (red.). 2009. Nowe media a media tradycyjne. Prasa, reklama, Internet. Toruń: Wydawnictwo Adam Marszałek, ss. 319
}

W iek XXI przyniósł nam nowe formy komunikacji z otoczeniem, za ich przyczyną granice, odległość czy czas mają coraz mniejsze znaczenie. Internet pozwala porozumiewać się ludziom na wiele sposobów, które wcześniej nie były możliwe, zarówno jeśli chodzi o komunikowanie pomiędzy jednostkami, jak i masowe. Jednocześnie wraz z narastającym uwielbieniem dla nowych technologii pojawiają się obawy dotyczące ich wpływu na istniejące od lat komunikatory, ale również na samych użytkowników sieci.

Recenzowana książka jest próbą znalezienia odpowiedzi na pytania o przyszłość mediów masowych w nowej, zmieniającej się rzeczywistości. Warto zaznaczyć, że na publikację złożyły się artykuły reprezentantów kilku dyscyplin naukowych, rekrutujących się z różnych ośrodków w Polsce. Otrzymaliśmy interesujący wielogłos: politologów, socjologów, medioznawców, polonistów, prawników, których łączy to, iż zajmują się tematyką nowych mediów. Sam redaktor tomu, Marek Jeziński, choć specjalizuje się w marketingu politycznym, jest autorem szeregu tekstów o interaktywnej komunikacji (zob. artykuł o funkcjach blogów politycznych).

Książka porusza problem relacji między mediami tradycyjnymi (prasa, radio, telewizja) a nowymi formami komunikacji, możliwymi dzięki dostępowi do sieci. Pojawienie się kolejnych komunikatorów zmienia nie tylko media masowe, ale także wiele dziedzin z nimi powiązanych, przykładowo reklamę czy książkę. Najważniejsza kwestia to poziom, zakres zmiany, jaki dokonuje się w przypadku „starych" mediów pod wpływem nowych technologii. Czy te drugie są dla nich zagrożeniem, czy wręcz odwrotnie - stanowią impuls do dalszego rozwoju? Treść recenzowanej pracy prowadzi do uzyskania odpowiedzi na to i wiele innych pytań.

Publikacja składa się z czterech części. W pierwszej analizowane są relacje między tradycyjnymi a nowymi mediami, głównie w aspekcie szans i zagrożeń dla prasy, radia i telewizji ze strony Internetu. Druga poświęcona jest zagadnieniu reklamy i zmianom, jakie zachodzą na skutek umieszczania jej w sieci. Trzecia dotyczy badań nad prasą i jej funkcjonowaniem we współczesnym świecie. Ostatnia, czwarta część koncentruje się na zagadnieniu samego Internetu; jego wpływu na multiplikację sposobów komunikacji, ale również tworzenie zagrożeń dla samego 
odbiorcy narażonego na uzależnienia, łatwy dostęp do treści pornograficznych czy możliwość szybkiego konstruowania własnych przekazów, nie zawsze mających walor wysokiej jakości.

Najważniejsze pytanie, jakie stawiają sobie autorzy wielu tekstów, brzmi: czy nowe media wyeliminują media tradycyjne? Zdaniem Anetty Grzesik-Robak nowe technologie nie są zagrożeniem dla tradycyjnych środków masowego przekazu, a nawet mogą przyczynić się do ich rewitalizacji i zróżnicowania. Potwierdzają to rozważania Stanisława Jędrzejewskiego, który przedstawia alternatywy dla radia w świecie cyfrowym, rysując obiecujące scenariusze jego rozwoju; podobnie czyni Piotr Ziarek w przypadku telewizji internetowej. Małgorzata Kosiarz i Anna M. Zarychta dokonują oglądu tego problemu z innej strony, mianowicie szkicując historię i działanie radia internetowego. Szkoda, że ich praca jest pozbawiona głębszych analiz na temat perspektyw rozwoju tego medium.

Wątpliwości na temat relacji „nowe media a media tradycyjne” pozbędziemy się także po lekturze artykułów poświęconych funkcjonowaniu prasy. Katarzyna Maciejewska oraz Lidia Pokrzycka badały elektroniczne wersje prasy lokalnej, pierwsza - odwołując się do przykładu "Gazety Olsztyńskiej”, druga - analizując rynek prasowy Lubelszczyzny. Katarzyna Maciejewska stwierdza, że postępująca konwergencja mediów zmusi nie tylko prasę, ale również radio i telewizję do głębokich przeobrażeń, a Internet będzie dla przeciętnego odbiorcy podstawowym „pasem transmisyjnym" wydarzeń. Natomiast korzystanie z tradycyjnych form przekazu będzie jedynie pewną modą, wyrazem snobizmu. Lidia Pokrzycka przedstawia sytuację dzienników i czasopism na terenie Lubelszczyzny oraz stopień popularności Internetu wśród nich. Jest to o tyle uzasadnione, że strony internetowe gazet zmieniają ich wizerunek, jednocześnie będąc doskonałym nośnikiem reklamy. Oferta internetowa jawi się jako dużo bogatsza niż wersja papierowa, ale to wcale nie degraduje prasy, jest ona tylko mniej zasobna w przekazy reklamowe, a te zamieszczane online przynoszą zyski wydawcom mediów tradycyjnych.

W przytoczonych tekstach autorzy nie traktują sieci jako zagrożenia dla tradycyjnych komunikatorów. Podobne zdanie prezentuje również Bara Ndiaye, który twierdzi, że obawa przed wyeliminowaniem mediów tradycyjnych przez nowe technologie jest nieuzasadniona, gdyż w historii żadne nowe medium nie zagroziło „staremu”, istniejącemu wcześniej. Gdyby jednak zaimplementować koncepcję Radosława Sajny - aby w imię ochrony drzewostanu naszej planety wyeliminować papierową prasę na rzecz tej elektronicznej - media oparte na tradycyjnej komunikacji mogłyby rzeczywiście nie przetrwać na rynku. Jednak wydaje się, że taka wizja nie może zostać szybko zrealizowana, chociażby ze względu na przywiązanie ludzi do "starych” mediów. Większość badaczy wypowiadających się w niniejszej pracy jest jednak zdania, że obecnie Internet nie zagraża istnieniu tradycyjnych mediów, jednakowoż pod warunkiem, że te będą inwestować w rozwój nowych technologii. 
W niektórych przypadkach sieć jest doskonałym rozwiązaniem problemów nurtujących tradycyjne środki masowego przekazu. Ilustracją tego zjawiska jest niewątpliwie reklama, dla której Internet przynosi nowe rozwiązania w zakresie i sposobach oddziaływania na konsumentów. Niemniej jednak artykuły zamieszczone w Nowych mediach... z reguły negatywnie odnoszą się do omawianej tu zależności. Przykładowo Jacek Sobczak opisuje granice prawne reklamy w Internecie, wskazując, że polskie prawo nie nadąża za rozwojem tej dziedziny. Multiplikacja przekazów reklamowych w sieci, różnorodność form oraz treści z jednej strony pozwalają na szeroką promocję, ale z drugiej są przyczyną wielu zagrożeń dla samych użytkowników, szczególnie tych niepełnoletnich. Reklama wirtualna jest o wiele bardziej perswazyjna od tej tradycyjnej, właśnie między innymi ze względu na różnorodność form przekazu. Pisze o tym Wiktor Szewczak, który wykazuje, że reklamy w sieci koncentrują się głównie na stylu, formie i kreowaniu wyobrażeń, a nie na wskazywaniu użytkowej wartości, treści czy zawartości reklamowego produktu. Poprzez swoją zróżnicowaną formę i wirtualność zwiększa się perswazyjność przekazu i oddziaływania na odbiorców poza ich świadomością. Dlatego, zdaniem autora, stare reklamy w nowych mediach są formą oporu przeciwko przemocy ikonicznej, która często występuje w wirtualnych przekazach. Podobne zdanie prezentuje Karolina Bachoń, pisząc o obrazie kobiety w reklamie internetowej. Autorka zaznacza, że jest on nadal stereotypowy, przy czym winą za ten stan rzeczy należy obarczyć nie tylko mężczyzn, ale również same kobiety, które są propagatorkami stereotypowych ról i wizerunków. Bardziej optymistyczny w tym zakresie jest artykuł Małgorzaty Sobocińskiej, która wskazuje na możliwości reklamy w Internecie poprzez rozkwit klipów wideo.

Rozwój nowych technologii wpływa także na funkcjonowanie innych dziedzin, takich jak literatura czy film. Sebastian D. Kotuła pisze o konwergencji mediów na przykładzie relacji książki i Internetu. Jego zdaniem pojawianie się nowych technologii stymuluje rozwój mediów tradycyjnych i na odwrót, Internet bowiem wykorzystuje zdobycze starych komunikatorów. Ponadto konwergencja jest ciągłym procesem, dlatego nie od razu zawłaszcza sobie całą przestrzeń, na której poruszają się „stare” media. Iwona Anna Ndiaye, opisując przyszłość literatury sieciowej na przykładzie rzeczywistości rosyjskiej, przedstawia walkę miedzy zwolennikami i przeciwnikami takiej formy literackiej ekspresji. Zaznacza, że sieć może być istotna dla rozwoju literatury, gdyż ma ona swoich nowych czytelników, którzy niekoniecznie czytaliby książki w wersji papierowej. Ciekawe rozważania prezentuje również Wojciech Otto, badający krótkie formy filmowe w Internecie, zamieszczane głównie w portalu YouTube. Autor wysuwa twierdzenie, że taka forma ekspresji sprzyja rozwojowi kina alternatywnego i tworzeniu filmowej kultury. Wydaje się jednak, że w rozważaniach z tego zakresu nie wolno pominąć zagrożeń, które niesie za sobą łatwość umieszczania filmów w tego typu serwisach. Jakość oraz charakter wielu prezentowanych 
tam materiałów może bowiem podważać argumenty na rzecz swobody tworzenia kultury.

W książce znajdują się również teksty, które dotyczą analizy słabych i mocnych stron Internetu widzianych z perspektywy samych jego użytkowników. Piotr Celiński porusza kwestię nowej formy porozumiewania się ludzi za pomocą interfejsów (język i formuła technologiczno-programistyczna umożliwiająca dwukierunkowe porozumiewanie się człowieka i mediów). Ta komunikacja, jego zdaniem, ma swoje wady, ponieważ istnieje nadmiar informacji, a natychmiastowe ich podawanie nierzadko skutkuje wprowadzaniem ludzi w błąd. $Z$ drugiej strony, konwergencja zmienia komunikację i daje szansę na jej szybki rozwój. Ważne zagadnienie porusza Wit Hubert, który pisze o cyfrowym wykluczeniu. Jego zdaniem miarą wykluczenia staje się nie tyle brak dostępu do samej sieci, ile brak aktywnej partycypacji we wszystkim, co daje Internet. Ludzie, wedle opinii autora, powinni być nie tylko konsumentami kultury sieciowej, ale również jej producentami, co jest charakterystyczne głównie dla młodych internautów. Ryszard Poprawa w swoim tekście także odnosi się do zagrożeń związanych z korzystaniem z sieci - w tym przypadku do uzależnienia od Internetu. Jednak konkludując, zaznacza, że sieć jako medium i technologia nie jest czynnikiem sprawczym niebezpieczeństw, zagrożenie stwarza bowiem sam człowiek, który nie potrafi oddzielić tego, co realne i wirtualne, od tego, co dobre i złe. W niniejszy problem wpisują się rozważania Marcina Kociuby, który zastanawia się nad odpowiedzialnością użytkownika grup dyskusyjnych w dobie kultury Web 2.0. Badacz zaznacza, że współcześnie problem ten wymaga szerokiej kodyfikacji, gdyż brak zasad dyskusji w grupach społecznościowych powoduje m.in. wzrost agresywności w przekazywanych treściach.

Przytoczone powyżej zagadnienia (a także szereg innych, wcześniej nieprzywołanych) przekładają się na bogatą i ważną z punktu widzenia badacza nowych mediów treść książki. Walorem pracy jest jej interdyscyplinarność oraz szeroka paleta poruszonych problemów, z tego chociażby względu publikacja stanowi istotny wkład w rozwój nauki o komunikowaniu. Praca jest użytecznym źródłem wiedzy dla młodych naukowców, rozpoczynających dopiero swoją przygodę z nowymi mediami, jak i dla tych bardziej zaawansowanych, pragnących zapoznać się ze współczesnymi badaniami na temat funkcjonowania mediów tradycyjnych w dobie rozwoju nowych komunikatorów.

Aleksandra Seklecka (Uniwersytet Mikołaja Kopernika w Toruniu) 